\title{
Wspomnienie o doktorze Stanisławie Srockim
}

Niespodziewana, przedwczesna śmierć naszego Przyjaciela i Kolegi Staszka Srockiego, doktora nauk prawnych i prezesa Regionalnej Izby Obrachunkowej w Białymstoku, wywołuje wiele, także wspólnych, wspomnień pracy naukowej, działalności publicznej, wspólnych życiowych doświadczeń. Jego dorobek naukowy i osiągnięcia w służbie publicznej są znane; wspomnienie podyktowane jest wszakże potrzebą dania świadectwa i podziękowania za Jego osiągnięcia w działalności naukowej i służbie publicznej.

Stanisław Kazimierz Srocki, syn Leona i Wandy z domu Kusiak, urodził się 5 stycznia 1949 r. w Radomiu. Maturę uzyskał w renomowanym radomskim Liceum Ogólnokształcącym im. Jana Kochanowskiego. Od 1968 r. związany był z Białymstokiem, gdzie rozpoczął studia administracyjne w białostockiej Filii UW; kontynuował je - na kierunku prawa - na Wydziale Prawa Uniwersytetu Warszawskiego. Do Białegostoku powrócił w 1974 r., podejmując pracę na stanowisku asystenta na Filii UW. Po obronie pracy doktorskiej, przygotowanej na temat: „Przekazywanie gruntów rolnych" pod kierunkiem Profesora Andrzeja Stelmachowskiego, na Wydziale Prawa UW, uzyskał stopień naukowy doktora nauk prawnych i został zatrudniony na stanowisku adiunkta w 1983 r. Równolegle w Sądzie Wojewódzkim w Białymstoku odbył aplikację sądową i zdał egzamin sędziowski. Ożenił się z Białostocczanką, także prawniczką, Hanną Sikorską, z którą stworzyli szczęśliwą Rodzinę wraz z synami Wojciechem, Janem i Andrzejem, również prawnikami.

Ze wspomnieniem Kolegi Staszka Srockiego ściśle wiąże się osoba Profesora A. Stelmachowskiego, ponieważ miał On ogromny wpływ na nasze życie - był naszym promotorem, kształtował osobowość i system wartości, nauczył funkcjonalnego podejścia do prawa i zintegrował nas w zespół Przyjaciół. Spotkaliśmy się ze Staszkiem właśnie jako młodzi asystenci Profesora, w roku 1974, w naszej białostockiej Filii Uniwersytetu Warszawskiego. Przeżyliśmy ze Staszkiem razem, zawodowo i towarzysko, 45 lat. W latach 1974-1992 wspólnie pracowaliśmy na uczelni. Od 1993 r., kiedy Staszek został prezesem RIO, podtrzymywaliśmy przyjazne kontakty, także naukowe i badawcze.

Profesor Stelmachowski, jako znany opozycjonista wobec ówczesnego systemu władzy komunistycznej, włączał nas w aktywną realizację przemian społecz- 
no-politycznych, prowadzących do obalenia tego systemu. Mam tu na myśli dwa wielkie ruchy: solidarności oraz samorządności. Przemiany te angażowały całe społeczeństwo. Solidarność i samorządność „wydarzyła się” nam wszystkim. Nawiązuję tu do pięknego sformułowania papieża Jana Pawła II, który w Sejmie oznajmił radośnie: „Ale nam się wydarzyło!” Wydarzyło się i nam, Staszkowi i mnie, z tym, że aktywność w realizacji idei solidarności nie ograniczała się do terenu uczelni, gdzie byliśmy oczywiście członkami komisji zakładowej NSZZ „Solidarność”. Z rekomendacji Profesora, jako Jego uczniowie, służyliśmy pomocą prawną w organizacji związków pracowniczych w wielu zakładach pracy, doradzaliśmy zarządowi regionu, a także, z racji znajomości prawa rolnego, Solidarności rolników indywidualnych. W tych działaniach rekomendacja Profesora stanowiła dla nas legitymację zapewniającą ludzkie zaufanie. Robiliśmy to pracując na uczelni, choć nauka i dydaktyka w roku akademickim 1980/81 zeszły na dalszy plan.

W momencie odzyskania wolności obywatelskiej, co miało miejsce blisko 30 lat temu (1989-1990), idea solidarności odżyła w różnych formach organizacyjnych samorządności: terytorialnej i zawodowej. Razem ze Staszkiem zaangażowaliśmy się niezwykle aktywnie w organizację samorządu terytorialnego, stanowiącego w istocie najważniejszą zmianę ustrojową w naszym kraju. W pierwszej fazie były to prace nad projektem ustawy o samorządzie terytorialnym, prowadzone pod auspicjami Senatu, jako nowej izby parlamentu. W Senacie pierwszym marszałkiem był Profesor Stelmachowski, więc siłą rzeczy byliśmy w te prace włączeni. Marszałek A. Stelmachowski, korzystając z inicjatywy ustawodawczej przysługującej Senatowi, wniósł projekt ustawy do Sejmu, który 8 marca 1990 r. uchwalił ustawę o samorządzie terytorialnym (w pierwszym okresie były to gminy). I wówczas rozpoczął się proces jej wdrażania. Zakres zmian ustrojowych był tak wielki, że powołano w tym celu specjalne struktury. Był to minister - członek rządu ds. samorządu terytorialnego - prof. J. Regulski, a w województwach powołano delegatów rządu ds. samorządu. W pierwszym okresie mnie powierzono tę funkcję, a od 1 września 1990 r. do 31 grudnia 1992 r. dr Srocki pełnił kolejno funkcję delegata Pełnomocnika Rządu ds. Samorządu Terytorialnego w województwie białostockim oraz Pełnomocnika Wojewody Białostockiego ds. Samorządu Terytorialnego. Na Nim spoczął wielki ciężar doradztwa i szkolenia samorządu w początkowych latach działania organów stanowiących i wykonawczych. W tym czasie orzekał również w Krajowej Komisji Uwłaszczeniowej.

Ważną cezurą w życiu zawodowym Staszka było utworzenie, w 1993 roku, regionalnych izb obrachunkowych. Staszek objął stanowisko prezesa RIO w Białymstoku, które piastował aż do chwili śmierci. Nowy pracodawca postawił wówczas wymóg wyłączności zatrudnienia, więc Staszek wziął urlop na uczelni (jako kierownik Katedry Prawa Cywilnego nie byłem tym zachwycony), zachował jednak rozmaite kontakty naukowe (badania naukowe, konferencje). Na ostatniej, wspólnej 
konferencji spotkaliśmy się w dniu 6 grudnia 2018 r. Umówiliśmy się na spotkanie 5 stycznia, w dniu 70. urodzin Staszka; do spotkania już, niestety, nie doszło.

Przez ostatnich 26 lat głównym polem działalności zawodowej i naukowej dra S. Srockiego było funkcjonowanie regionalnych izb obrachunkowych i samorządu terytorialnego. W tej dziedzinie pełnił wiele funkcji organizacyjnych. W latach 1998-2006 pełnił funkcję wiceprzewodniczącego Krajowej Rady Regionalnych Izb Obrachunkowych; w roku 2006 objął funkcję przewodniczącego tej Rady (kadencja 2006-2008). S. Srocki był też arbitrem Urzędu Zamówień Publicznych od 1995 do 2004 roku; członkiem Kolegium Urzędu Zamówień Publicznych od 2002 roku, a następnie od 2004 roku członkiem Rady Zamówień Publicznych, w tym w latach 2006-2008 jej wiceprzewodniczącym. W roku 2007 S. Srocki został powołany na przewodniczącego komisji kwalifikacyjnej w pierwszym postępowaniu kwalifikacyjnym na członków Krajowej Izby Odwoławczej.

Działalność zawodowa dra S. Srockiego, jako prezesa RIO, nie może być przedmiotem moich osobistych wspomnień, ponieważ przyglądałem się tej instytucji jedynie z zewnątrz. Chciałbym wszakże podzielić się ogólną refleksją. RIO jest instytucją trudną, działa bowiem na styku administracji rządowej z samorządem terytorialnym. Jest to pole wielu potencjalnych i rzeczywistych konfliktów, zwłaszcza gdy rząd i samorząd należą do różnych opcji politycznych. Skoro S. Srocki „,przetrwał", na stanowisku prezesa RIO, wszystkie zmiany polityczne ekip rządowych w tym okresie, to znaczy, że kierował izbą w sposób mądry. Kierował mądrze nie w sensie koniunkturalnym, aby zachować stanowisko, lecz aby mądrze stosować prawo z troską o ochronę samodzielności samorządu. W mojej ocenie, a obserwowałem to z pozycji sędziego NSA, prezes Srocki nie był biurokratycznym, srogim nadzorcą, lecz raczej dobrym duchem i opiekunem jednostek samorządu terytorialnego.

Obowiązki prezesa izby dr S. Srocki łączył z aktywnością w sferze legislacyjnej. Przez wiele lat był głównym ekspertem izb obrachunkowych w pracach komisji Sejmu i Senatu, w szczególności nad nowelizacjami ustawy o regionalnych izbach obrachunkowych oraz w pracach nad ustawą o kontroli wewnętrznej w administracji. W latach 1995-1997 brał udział w pracach zespołowych, prowadzonych w ramach Instytutu Spraw Publicznych w Warszawie, nad projektem reformy ustroju terytorialnego na szczeblu województwa; efektem tych prac koncepcyjnych zespołu były projekty ustaw o samorządzie wojewódzkim oraz o rządowej administracji wojewódzkiej. Był współtwórcą periodyku naukowego „Finanse Komunalne” oraz członkiem kolegium redakcyjnego tego pisma, od jego początku (kwiecień 1994) aż do numeru 1-2/ 2019. Doktor S. Srocki posiada też znaczący dorobek publikacyjny dotyczący m.in. zagadnień funkcjonowania i kompetencji regionalnych izb obrachunkowych. Można tu przytoczyć opracowania: Kompetencje regionalnych izb ob- 
rachunkowych, (w:) Reforma administracji publicznej 1999 - dokonania i dylematy, Warszawa 2001; Regionalne izby obrachunkowe w Polsce $w$ latach 1993-2003, Wrocław 2003 (red.). Dokonania S. Srockiego zostały dostrzeżone i nagrodzone w roku 2014, kiedy to podczas obchodów 20-lecia izb obrachunkowych otrzymał Krzyż Kawalerski Orderu Odrodzenia Polski.

Finalizując swoje wspomnienia chciałbym zwrócić uwagę na system wartości, którymi kierował się S. Srocki w życiu prywatnym, koleżeńskim i zawodowym. Co do systemu wartości ważnych w jego życiu to, po zastanowieniu się, pragnę stwierdzić, że zasadniczą cechą wyróżniającą Staszka była Jego mądrość życiowa. Doktor Stanisław Srocki żył i działał mądrze. Filozofowie mówią, że mądrość jest syntezą wiedzy, uczciwości i dobroci. Gdy chodzi o wiedzę, to Staszek był wybitnym prawnikiem, łączącym znajomość doktryny prawa i to wielu dyscyplin (prawo cywilne, rolne, finansowe, prawo samorządu terytorialnego), z umiejętnością stosowania prawa w praktyce; w dziedzinie finansów komunalnych był ekspertem rangi krajowej. Pragnę też zaznaczyć, że w środowisku naukowym cieszył się autorytetem profesorskim; Jego stanowisko często rozstrzygało spory doktrynalne i jurysdykcyjne. Był człowiekiem wielkiej wiedzy.

Gdy chodzi o cechy uczciwości i dobroci, to stanowią one integralną część systemu wartości moralnych prezentowanych w postawie życiowej Staszka. Te wartości to: prawość, uczciwość, odpowiedzialność, troska o dobro wspólne, solidarność ze słabszym, a także kierowanie się społeczną nauką Kościoła. I co ważne, u Staszka był to trwały system wartości, bez odstępstw koniunkturalnych. Chcę tu odwołać się również do autorytetu Ojca Ludwika Wiśniewskiego, który rozważając wartości szczególnie ważne dla pełnienia służby publicznej wymieniał: bezinteresowność, szacunek dla innych oraz zdolność i dążenie do kompromisu. Z całą powagą zaświadczam, że właśnie te cechy charakteryzowały także długą, ponad 25-letnią służbę publiczną prezesa Stanisława Srockiego. I takim, mądrym, dobrym i przyzwoitym Człowiekiem i Przyjacielem pozostanie w naszej wspólnej pamięci.

Stanisław Prutis 


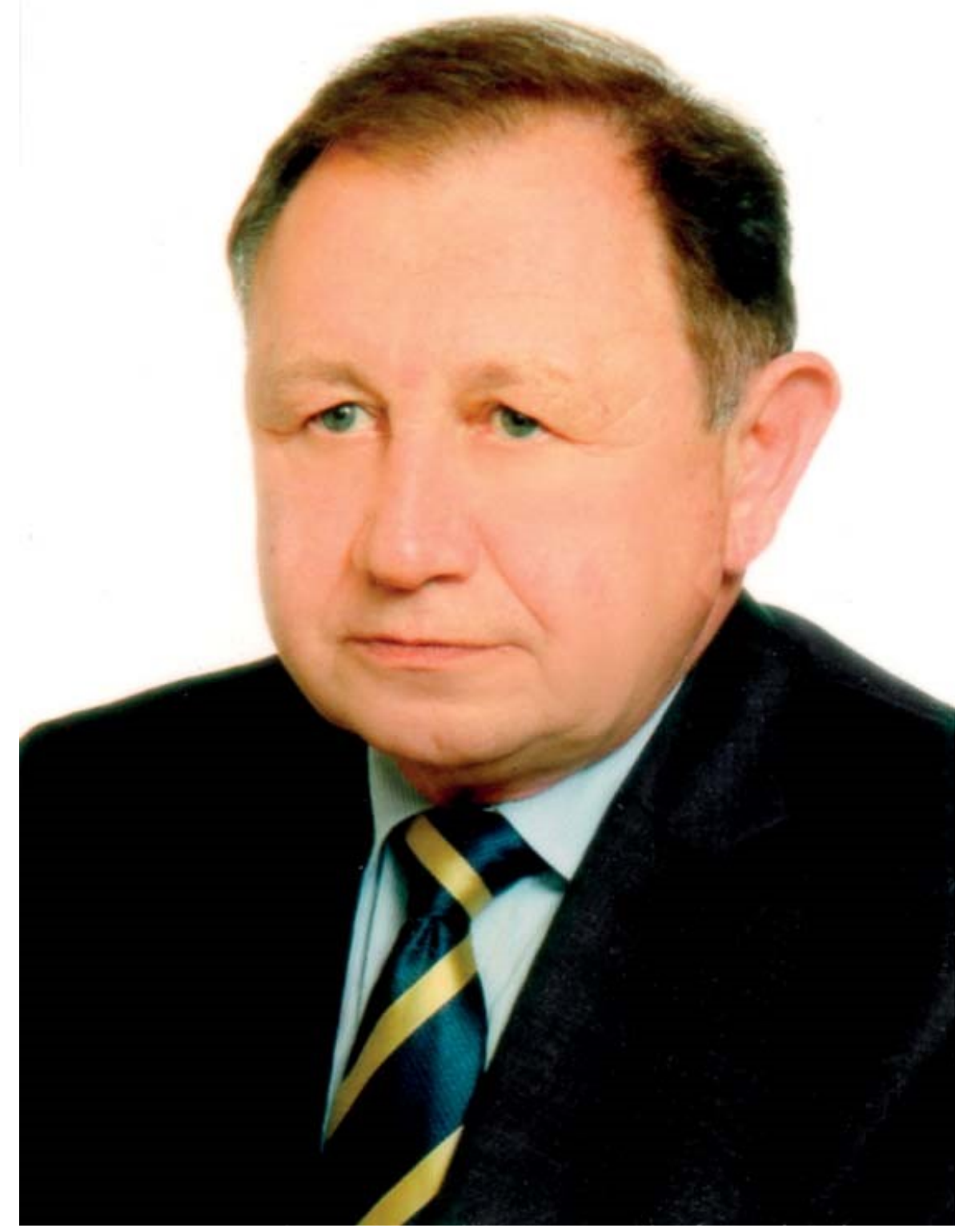

Dr Stanisław Srocki (1949-2019) 